\title{
NILAI BUDI PEKERTI MELALUI TEMBANG DOLANAN ANAK
}

\author{
M. A Dhalu*, Sedya Santosa \\ Pascasarjana Pedididikan Guru Madrasah Ibtidaiyah, Uin Sunan Kalijaga, Indonesia \\ *Email: milantiedhalu@gmail.com
}

\begin{abstract}
Informasi Artikel Abstrak

Kata kunci:

Tembang Dolanan, Makna,

Nilai Pendidikan

Diterima: $16-03-2020$

Disetujui: 03-07-2020

Dipubikasikan: 26-10-2020

Penelitian ini bertujuan untuk mempertahankan kembali tembang dolanan anak-anak di Desa Srimulyo dan permainannya yang kini telah dilupakan dan banyak yang tidak diketahui oleh anak-anak di desa tersebut. Hasil penelitian menunjukkan bahwa tembang dolanan memiliki nilai karakter yang sangat penting dalam menumbuhkan karakter percaya diri, mandiri, bertanggung jawab dan beberapa karakter yang perlu dibentuk pada anak. Pentingnya tembang dolanan yang merupakan warisan budaya di pertahankan hingga kini yaitu nilai pendidikan yang terkandung di dalamnya yang mengajarkan anakanak agar memliki nilai budi pekerti, nilai keagamaan, nilai sosial, dan nilai budaya yang baik. Metode yang digunakan dalam penelitian ini adalah metode penelitian deskriptif yang bersifat kualitatif. Instrumen pada penelitian ini adalah penelitian secara individu, pengumpulan data, dan wawancara dengan narasumber. Dari hasil perolehan data dilapangan ada beberapa tembang dolanan anak-anak yang dari setiap baitnya memiliki makna dan nilai pendidikan yang berbeda-beda serta mengajarkan tentang nilai budi pekerti, nilai religius, nilai budaya dan nilai sosial yang dapat diketahui dari menganalis makna pada tembang dolanan anak-anak.
\end{abstract}

\section{PENDAHULUAN}

Pendidikan Nasional bertujuan untuk berkembangnya potensi peserta didik agar menjadi manusia yang beriman dan bertaqwa kepada Tuhan Yang Maha Esa, berakhlak mulia, sehat, cakap, kreatif, mandiri, dan menadi warga negara yang demokratis serta bertanggung jawab.

Indonesia memiliki pancasila dan nilai-nilai budaya yang luhur dan menjunjung tinggi kerukunan dan tenggang rasa. Salah satu cara membentuk watak dan pribadi bangsa Indonesia ini adalah dengan melalui pendidikan. Pendidikan di Indonesia ini di harapkan mampu membentengi hal-hal negatif yang ada di negara Indonesia.

Sesungguhnya pendidikan budi pekerti selama ini telah diterapkan lewat pendidikan agama, khususnya pendidikan agama Islam, di sekolah telah di berikan dalam berbagai aspek, yakni keimanan, ibadah, syari'ah, 
akhlak, al-Quran, muamalah dan tarikh. Di dalam materi yang terkait dengan pendidikan budi pekerti adalah akhlak. Dengan demikian pendidikan akhlak secara langsung berhubungan dengan pendidikan budi pekerti.

Nilai adalah suatu tipe kepercayaan yang berada dalam ruang lingkup sistem kepercayaan dalam mana seseorang bertindak atau menghindari suatu tindakan, atau mengenai sesuatu yang pantas atau tidak pantas dikerjakan. Dari pengertian tersebut dapat diketahui bahwa nilai merupakan sifat yang mengiringi sesuatu (sistem kepercayaan) yang telah terhubung dengan subyek yang memberi makna(Chabib Thoha, 1996:60).

Budi pekerti bukan mata pelajaran, tetapi merupakan program pendidikan untuk menciptakan suasana kondusif dalam menerapakan nilai-nilai budi pekerti. Pengertian budi pekerti secara operasional adalah upaya untuk membekali peserta didik melalui kegiatan bimbingan, pengajaran dan latihan selama pertumbuhan dan perkembangan dirinya sebagai bekal masa depan agar memiliki hati nurani yang bersih, berperangai baik, yang tercermin pada perilaku berupa ucapan, perbuatan, sikap pikiran, perasaan, kerja dan hasil karya berdasarkan nilai-nilai agama serta norma dan moral.

Secara etimologis, istilah budi pekerti, atau dalam bahasa Jawa disebut budi pakerti, dimaknai sebagai budi berarti pikir, dan pakerti berarti perbuatan. Menurut Ensiklopedia Pendidikan, budi pekerti diartikan sebagai kesusilaan yang mencakup segi-segi kejiwaan dan perbuatan manusia; sedangkan manusia susila adalah manusia yang sikap lahiriyah dan batiniyahnya sesuai dengan norma etik dan moral.

Tujuan pendidikan budi pekerti yaitu agar peserta didik memiliki kemampuan dan kecakapan berpikir, menjadi anggota masyarakat yang bermanfaat dan memiliki kemampuan yang terpuji.

Budi pekerti merupakan hal yang sangat penting dalam kehidupan manusia, baik sebagai makhluk pribadi maupun makhluk sosial. Budi pekerti seseorang akan tampak pada sikap dan perilakunya. Orang yang berbudi pekerti baik akan selalu bersikap dan berperilaku baik. Sebaliknya, orang yang sikap dan perilakunya tidak baik, menunukkan bahwa budi pekertinya juga tidak baik (Suyami, 2015:1).

Budi pekerti berasal dari dua kata yaitu budi dan pekerti. Kata budi, berarti alat batin yang merupakan paduan dan perasaan untuk menimbang baik dan buruk, sedangkan pekerti artinya perangai, watak, tabiat akhlak. Dengan kata lain budi pekerti artinya alat yang digunakan batin untuk menimbang baik atau buruk akhlak atau watak seseorang (Suyami, 2015:191).

Pengertian budi pekerti mengacu pada pengertian dalam bahasa inggris, yang diterjemahkan sebagai moralitas. Moralitas mengandung beberapa pengertian antara lain : (a) adat istiadat, (b) sopan santun, dan (c) perilaku. Namun, pengertian budi pekerti secara hakiki adalah perilaku. Sementara itu menurut draf kurikulum berbasis kompetensi, budi pekerti berisi nilai-nilai perilaku manusia yang akan diukur menurut kebaikan dan keburukannya melalui norma agama, norma hukum, tata krama dan sopan santun, norma budaya dan adat istiadat masyarakat. Budi pekerti akan mengidentifikasikan perilaku positif yang diharapkan dapat terwujud dalam perbuatan, perkataan, pikiran, sikap, perasaan, dan kepribadian peserta didik (Nurul Zuriah, 2015:1).

Tembang dolanan anak-anak Jawa merupakan salah satu karya sastra yang berbentuk lisan. Dikatakan lisan sebab pada zaman dahulu tembang dolanan dikenal dari mulut ke mulut di masyarakat. Menurut Sukadaryanto 
(2010:1) sebagian besar sastra dalam bentuk lisan jarang diketahui pengarangnya dan merupakan karya kolektif. Tembang dolanan tidak ada yang mengetahui siapa pengarangnya, sebab masyarakat mewariskannya secara turun temurun atau

kolektif.

Tembang dolanan yang sarat akan makna dapat dijadikan sarana pembentukan karakter anak. Maknamakna yang terkandung di dalam tembang dolanan anak-anak Jawa menjadi salah satu sarana orang tua atau guru dalam memberikan nasihat kepada anak. Misalnya karakter percaya diri, mandiri, bertanggung jawab dan beberapa karakter yang perlu dibentuk pada anak.

Menyanyikan tembang dolanan diiringi dengan gerakan yang sesuai dengan isi lagu secara tidak langsung akan membuat anak senang dan larut mengikuti permainan. Hal ini merupakan salah satu cara untuk melestarikan tembang dolanan anak-anak Jawa. Dilihat dari sistem bermainnya tembang dolanan akan menambah keakraban seorang anak dengan teman-temannya, melatih anak bersosial dan berkomunikasi dengan orang lain.

Melihat kenyataan yang ada sekarang ini, sebagai generasi muda haruslah berbuat banyak demi kelestarian budaya dan kesenian tradisional yang hampir punah. Tembang dolanan sebagai warisan nenek moyang yang mempunyai nilai-nilai luhur harus terus dilestarikan. Namun ironis, sekarang ini generasi muda khususnya anakanak yang tinggal di daerah yang banyak mendapat pengaruh budaya modern pada umumnya tidak mengenal tembang dolanan berbahasa Jawa tersebut meskipun mereka orang Jawa. Mereka kurang berminat mempelajari apalagi menghafal tembang dolanan berbahasa Jawa tersebut.

Berdasarkan hasil observasi peneliti menemukan bahwa terdapat sanggar yang masih menjalakan kegiatan seperti tari, ketoprak, nembang, dan lagu-lagu tradisional lainnya. Latihan ini diakukan di sanggar sindu kusumo dan lawung bekso yang berada di desa payak wetan desa sri mulyo rt 03 Kecamatan piyungan kabupaten bantul, yogyakarta. Kegiatan sanggar berlangsung seminggu sekali dan di isi oleh anak-anak dari TK sampai SD. Selian melaksanakan kegiatan di sanggar biasanya kegiatan dilakuan di pinggir sungai agar anak tidak merasa jenuh. Dari kegiatan ini pelatih berharap mampu menumbukan nilai-nilai budaya yang harus dilestarikan. Memberikan nilai-nilai yang berkaitan dengan latihan dan menmbuhkan moral anak melalui kegiatan yang dilakukan bersamasama.

\section{METODE}

Metode yang digunakan dalam penelitian ini adalah metode penelitian kualitatif. Jenis penelitian ini kualitatif deskriptif dengan pendekatan studi kasus. Penelitian kualitatif deskriptif merupakan salah satu dari jenis penelitian yang termasuk dalam jenis penelitian kualitatif. Adapun tujuan dari peneitian ini adalah untuk mengungkap kejadian atau fakta, keadaan, fenomena, variabel dan keadaan yang terjadi saat penelitian berlangsung dengan menyuguhkan apa yang sebenarnya terjadi. Metode deskriptif adalah satu metode angdigunakan untu membuat kesimpulan yang lebih luas. Metode penelitian studi kasus meneliti suatu kasus 
atau fenomena tertentu yang ada dalam masyarakat yang dilakukan secara mendalam untuk mempelajari latar belakang, keadaan, dan interaksi yang terjadi. Studi kasus dilakukan pada suatu kesatuan sistem yang berupa suatu program, kegiatan, peristiwa, atau sekelompok indvidu yang ada pada keadaan atau kondisi tertentu.

\section{HASIL PENELITIAN DAN PEMBAHASAN}

\section{Hasil Penelitian}

Secara umum, nilai adalah konsep yang menunjuk pada hal hal yang dianggap berharga dalam kehidupan manusia, yaitu tentang apa yang dianggap baik, layak, pantas, benar, penting, indah, dan dikehendaki oleh masyarakat dalam kehidupannya. Sebaliknya, hal-hal yang dianggap tidak pantas, buruk, salah dan tidak indah dianggap sebagai sesuatu yang tidak bernilai. Nilai adalah suatu bentuk penghargaan serta keadaan yang bermanfaat bagi manusia sebagai penentu dan acuan dalam menilai dan melakukan suatu tindakan. Dengan mengacu kepada sebuah nilai, seseorang dapat menentukan bagaimana ia harus berbuat dan bertingkah laku yang baik sehingga tidak menyimpang dari norma-norma yang berlaku.

Nilai-nilai budi pekerti menurut Kurikulum Berbasis Kompetensi Mata Pelajaran Budi Pekerti kelas I-VI Buram ke-6, Puskur Depdinas adalah sebagai beikut. Nilai-nilai budi pekerti d bawah ini merupakan uraian berbagai perilaku dasar dan sikap yang diharapkan dimiliki peserta didik sebagai dasar pembentkan pribadinya (Nurul Zuriah, 2015:198-199).

Tabel 1. Nilai-nilai budi pekerti menurut Kurikulum Berbasis Kompetensi

\begin{tabular}{|c|c|}
\hline Nilai Budi Pekerti & Deskripsi \\
\hline $\begin{array}{l}\text { 1. Meyakini adanya Tuhan Yang Maha Esa } \\
\text { dan selalu mentaati ajaran-Nya }\end{array}$ & $\begin{array}{l}\text { Sikap dan perilaku yang mencerminkan keyakinan dan kepercayaan } \\
\text { terhadap Tuhan Yang Maha Esa. }\end{array}$ \\
\hline 2. Menaati ajaran agama & $\begin{array}{l}\text { Sikap dan perilaku yang mencerminkan kepatuhan, tidak ingkar, dan } \\
\text { taat menjalankan perintah dan menghindari larangan agama. }\end{array}$ \\
\hline $\begin{array}{l}\text { 3. Memiliki dan mengembangkan sikap } \\
\text { toleransi }\end{array}$ & $\begin{array}{l}\text { Sikap dan perilaku yang mencerminkan toleransi dan penghargaan } \\
\text { terhadap pendapat, gagasan, dan tingkah laku orang lain, baik yang } \\
\text { sependapat maupun yangtidak sependapat dengan dirinya. }\end{array}$ \\
\hline 4. Memiliki rasa mneghargai diri sendiri & $\begin{array}{l}\text { Sikap dan perilaku yang mencerminkan penghargaan seseorang } \\
\text { terhadap dirinya sendiri dengan memahami kelebihan dan kekurangan } \\
\text { dirinya. }\end{array}$ \\
\hline 5. Tumbuhnya disiplin diri & $\begin{array}{l}\text { Sikap dan perilaku sebagai cerminan dari ketaatan, kepatuhan, } \\
\text { ketertiban, kesetiaan, ketelitian, dan keteratuan perilaku seseorang } \\
\text { terhadap norma dan aturan yang berlaku. }\end{array}$ \\
\hline
\end{tabular}

Budi pekerti adalah usaha sadar yang dilakukan dalam rangka menanamkan atau menginternalisasikan nilainilai moral ke dalam sikap dan prilaku peserta didik agar memiliki sikap dan prilaku yang luhur (berakhlakul karimah) dalam kehidupan sehari-hari, baik dalam berinteraksi dengan Tuhan, dengan sesama manusia maupun dengan alam/lingkungan. Secara konsepsional, Pendidikan Budi Pekerti dapat dimaknai sebagai usaha sadar melalui kegiatan bimbingan, pembiasaan, pengajaran dan latihan, serta keteladanan untuk menyiapkan peserta didik menjadi manusia seutuhnya yang berbudi pekerti luhur dalam segenap peranannya di masa yang akan 
datang. Pendidikan budi pekerti juga merupakan suatu upaya pembentukan, pengembangan, peningkatan, pemeliharaan dan perbaikan perilaku peserta didik agar mau dan mampu melaksanakan tugas-tugas hidupnya secara selaras, serasi, seimbang antara lahir-batin, jasmani-rohani, material-spiritual, dan individu-sosial (Haidar, 2004:43)

Penekanan pendidikan budi pekerti dan pengetahuan di sekolah harus diseimbangkan. Pengertian keseimbangan di sini lebih menekankan pada kebutuhan dan aspek perkembangan manusia. Untuk membantu melihat hal tersebut kiranya perlu dilihat perkembangan kognitifdan perkembangan moral. Dengan melihat tahapan-tahapan perkembangan moral dan perkembangan kognitif, bisa dilihat keseimbangan penekanan pendidikan budi pekerti dan pengetahuan.

Tembang dolanan berbahasa Jawa merupakan sarana untuk bersenang-senang dalam mengisi waktu luang dan juga sebagai sarana komunikasi yang mengandung pesan mendidik. Contoh tembang dolanan yang dimaksud adalah cublak-cublak suweng, gundul-gundul pacul, sluku-sluku bathok, ilir-ilir, dan masih banyak lagi. Tembang dolanan anak merupakan suatu hal yang menarik karena sesuai dengan perkembangan jiwa anak yang masih suka bermain, didalamnya juga mengandung ajaran-ajaran atau nilai-nilai moral budi pekerti. Dr. Suharko Kasaran, (Ketua Komisi Nasional Budi Pekerti) mengatakan bahwa apabila anak kurang/tidak dibina pendidikan budi pekerti sedini mungkin, pada umur 14 tahun anak itu akan mengembangkan sikap destruktif (cenderung ke arah brutal).

Daya konsentrasi anak tumbuh pada kelas kelas besar SD. Mereka dapat meluangkan lebih banyak waktu untuk tugas tugas pilihan mereka, dan seringkali mereka dengan senang hati menyelesaikannya. Tahap ini juga termasuk tumbuhnya tindakan mandiri, kerjasama dengan kelompok dan bertindak menurut cara cara yang dapat diterima lingkungan mereka. Mereka juga mulai peduli pada permainan yang jujur.

Selama masa ini mereka juga mulai menilai diri mereka sendiri dengan membandingkannya dengan orang lain. Anak anak yang lebih mudah menggunakan perbandingan sosial (social comparison) terutama untuk normanorma sosial dan kesesuaian jenis-jenis tingkah laku tertentu. Pada saat anak-anak tumbuh semakin lanjut, mereka cenderung menggunakan perbandingan sosial untuk mengevaluasi dan menilai kemampuan kemampuan mereka sendiri.

\section{Pembahasan Penelitian}

\section{Lirik Tembang Dolanan}

GUNDUL PACUL

Gundul gundul pacul cul gembelengan

Nyungoi-nyunggi wakul kul gembelengan

Wakul ngglimpang segane dadi sak latar

W akul ngglimpang segane dadi sak. latar 
SLUKU-SLUKU

Sluku-sluku bathok

Bathoke ela-elo

Si Rama menyang Solo

Oleh-olehe payung motha

Mak jenthit lolo lobah

Wong mati ora obah

Nek obah medeni bocah

Nek urip goleka dhuwit

\section{CUBLAK-CUBLAK SUWENG}

Cublak-cublak suweng

Suwenge ting gelenter

Mambu ketundung gudbel

Pak gempo lerak-lerek

Sopo ngguyu ndelekakbe

Sir-sir pong dele kopong

Sir-sir pong dele kopong

Sir-sir pong dele kopong

\section{ILIR-ILIR}

Lir-ilir, lir-ilir

Tandure wus sumilir

Tak ijo royo-royo

Tak sengguh temanten anyar

Cah angon, cah angon

Penekno blimbing kuwi

Lunyu-lunyu penekno

Kanggo mbasub dodotiro

Dodotiro, dodoiro

Kumitir bedah ing pinggir

Dondomono, jlumatono

Kanggo sebo mengko sore

Mumpung padhang rembulane

Mumpung jembar kalangane 
Yo sorako, sorak iyo!!

\section{Makna dan nilai budi pekerti yang Terkandung pada Tembang Dolanan}

- Gundul pacul artinya bahwa seorang pemimpin sesungguhnya bukan orang yang diberi mahkota tetapi dia adalah pembawa amanah. Kemuliaan seseorang tergantung 4 hal, yaitu bagaimana menggunakan mata, hidung, telinga dan mulutnya.

1. Mata digunakan untuk melihat kesulitan rakyat/masyarakat.

2. Telinga digunakan untuk mendengar nasehat.

3. Hidung digunakan untuk mencium wewangian kebaikan.

4. Mulut digunakan untuk berkata adil.

Jika empat hal itu lepas, maka lepaslah kehormatannya. 'gembelengan' artinya besar kepala, sombong dan bermain-main dalam menggunakan kehormatannya. Arti harafiahnya jika orang yg kepalanya sudah kehilangan 4 indera itu mengakibatkan: gembelengan (congkak/sombong). Nyunggi2 wakul (menjunjung amanah rakyat/orang banyak) gembelengan (sombong hati), akhirnya wakul ngglimpang (amanah jatuh gak bisa dipertahankan). Nilai pendidikan budi pekerti yang terkandung adalah bagaimana mejadi seorang pemimpin yang amanah, tidak sombong dan bertanggung jawab.

- Makna yang tersirat dalam tembang dolanan "Sluku-sluku bathok" yaitu nilai religius. Dalam syair tersebut bermakna manusia hendaklah membersihkan batinnya dan senantiasa berzikir mengingat Allah dengan menggelengkan kapala mengucapkan lafal laa illa ha illallah disaat susah maupun senang, di kala menerima musibah maupun kenikmatan, hidup mati manusia ditangan Allah, maka dari itu selagi masih hidup berbuat baiklah terhadap sesama, dan beribadah kepada Allah SWT karena Allah Maha segala-galanya, apabila sekali berkehendak mencabut nyawa seseorang, tak seorang pun mampu menolakkan. Nilai budi pekerti yang terkandung ialah sebagai umat islam kita harus senantiasa menginggat atas kebesaran Allah dan bersyukur dalam hal apapun. Menerima apapun dengan ikhkas dan selalu mengingat akan kematian dan kehidupan setelah kematian.

- Sebagai manusia biasa yang tercipta dari tanah. Makanya dalam permainan seorang anak harus telungkup mencium tanah seolah sedang sujud. Hanya manusia biasa yang tak tak tahu apa-apa. Namun manusia tetap ada hasrat nafsu sebagaimana nabi Adam dikeluarkan dari surga karena mencium wanita. Manusia mempunyai hasrat nafsu harta, tahta dan wanita. Dalam lagu daerah ini manusia tetap memenuhi hasratnya untuk mencari harta ("cublak-cublak suweng"). Namun harta tercecer dimana-mana dan semua orang pasti menginginkannya. Nlai budi pekerti yang terkandung ialah kita harus bersikap rendah diri, jujur, tidak serakah, sopan santun dan menjaga apapun yang kita miliki saat ini.

- Dalam syair tembang dolanan yang berjudul Ilir-ilir mengandung makna religius (keagamaan). Sedangkan maksud yang terkandung dalam tembang tersebut adalah kita sebagai umat manusia diminta bangun dari 
keterpurukan untuk lebih mempertebal iman dan berjuang untuk mendapatkan kebahagiaan seperti bahagianya pengantin baru. Meminta Si anak gembala untuk memetikkan buah blimbing yang diibaratkan perintah salat lima waktu. Yang ditempuh dengan sekuat tenaga kita tetap berusaha menjalankan Rukun Islam apapun halangan dan resikonya. Meskipun ibarat pakaian kita terkoyak lubang sana sini, namun kita sebagai umat diharapkan untuk memperbaiki dan mempertebal iman dan taqwa agar kita siap memenuhi panggilan Ilahi robbi. Nilai budi pekerti yang terkandung adalah rendah hati dalam kehidupan, selalu menjalankan perintah Allah dan menjauhi larangannya serta berusaha memperbaiki diri.

\section{Kesimpulan}

Berdasarkan hasil penelitian mengenai nilai budi pekerti melalui tembang dolanan di sanggar sindu kusma yang terletak di Desa Srimulyo Kec. Piyungan Kab. Bantul. Dapat disimpulkan bahwa : Terdapat 4 tembang dolanan anak-anak yang keseluruhannya berbahasa jawa yaitu tembang dolanan Gundul Pacul, Sluku-sluku Bathok, Cublak-cublak Suweng dan Lir-ilir. Dari keempat tembang dolanan tersebut merupakan tembang dolanan pengantar permainan anak-anak yang cara bermainnya dapat dilakukan dengan membutuhkan 5 orang anak atau lebih, sehingga mampu menumbuhan sikap kebersamaan, keceriaan, dan toleransi dalam pergaulan. Dari tembang dolanan anak-anak dapat menumbuhkan nilai-nilai karakter pada setiap diri anak-anak yaitu bertanggung jawab, jujur, tidak sombong, rendah diri, disiplin diri, dan saling menghargai. Dengan melihat kenyataan pada saat sekarang ini, sebagai generasi muda harus berbuat banyak demi melestarikan budaya dan kesenian tradisional yang hampir punah. Lagu dolanan meupakan salah satu aset seni budaya warisan leluhur bangsa yang mempunyai nilai luhur yang harus dilestarikan.

\section{Daftar Pustaka}

Chaib Thoha. 1996. "Pendidikan Islam”. Jakarta : Rajawali Pers.

Haidar Putra Daulay. 2004. "Pendidikan Islam dalam Sistem Pendidikan di Indonesia". Jakarta : Kencana Prenada Media Group.

Nurul Zuriah. 2015. "Pendidikan Moral \& Budi Pekerti dalam Perspektif Perubahan”. Jakarta : Bumi Aksara. Suyami, dkk. 2015. "Kajian Nilai Budi Pekerti dalam Serat Jayabaya”. Yogyakarta : BPNB. 